\title{
Trying to recollect past events: Confidence, beliefs, and memories
}

Citation for published version (APA):

Smeets, T., Merckelbach, H. L. G. J., Horselenberg, R., \& Jelicic, M. (2005). Trying to recollect past events: Confidence, beliefs, and memories. Clinical Psychology Review, 25, 917-934. https://doi.org/10.1016/j.cpr.2005.03.005

Document status and date:

Published: 01/01/2005

DOI:

10.1016/j.cpr.2005.03.005

Document Version:

Publisher's PDF, also known as Version of record

\section{Please check the document version of this publication:}

- A submitted manuscript is the version of the article upon submission and before peer-review. There can be important differences between the submitted version and the official published version of record.

People interested in the research are advised to contact the author for the final version of the publication, or visit the DOI to the publisher's website.

- The final author version and the galley proof are versions of the publication after peer review.

- The final published version features the final layout of the paper including the volume, issue and page numbers.

Link to publication

\footnotetext{
General rights rights.

- You may freely distribute the URL identifying the publication in the public portal. please follow below link for the End User Agreement:

www.umlib.nl/taverne-license

Take down policy

If you believe that this document breaches copyright please contact us at:

repository@maastrichtuniversity.nl

providing details and we will investigate your claim.
}

Copyright and moral rights for the publications made accessible in the public portal are retained by the authors and/or other copyright owners and it is a condition of accessing publications that users recognise and abide by the legal requirements associated with these

- Users may download and print one copy of any publication from the public portal for the purpose of private study or research.

- You may not further distribute the material or use it for any profit-making activity or commercial gain

If the publication is distributed under the terms of Article $25 \mathrm{fa}$ of the Dutch Copyright Act, indicated by the "Taverne" license above, 


\title{
Trying to recollect past events: Confidence, beliefs, and memories
}

\author{
Tom Smeets *, Harald Merckelbach, Robert Horselenberg, Marko Jelicic \\ Department of Experimental Psychology, Maastricht University, P.O. Box 616, 6200 MD Maastricht, The Netherlands
}

Received 6 October 2004; received in revised form 14 February 2005; accepted 10 March 2005

\begin{abstract}
Numerous studies claim to have shown that false memories can be easily created in the laboratory. However, a critical analysis of the methods employed in these studies indicates that many of them do not address memory in the strict sense of the word. Instead, some of these studies assess the confidence that participants have in a fictitious (childhood) event, while others pertain to false beliefs about childhood events. While it is difficult to draw precise demarcation lines, we argue that inflated confidence, false beliefs, and false memories are different phenomena. Keeping the origins of these studies in mind (i.e., people who file lawsuits on the basis of their recovered memories), we propose that a fruitful, but stringent definition of false memories would incorporate their consequences. Thus, we argue that this research domain would profit from studies looking explicitly at whether experimental manipulations intended to implant false memories have overt behavioral consequences.
\end{abstract}

(C) 2005 Elsevier Ltd. All rights reserved.

Keywords: Imagination; Confidence; False beliefs; False memories

Since the pioneering work of Bartlett (1932), research on memory has only gradually given up its preoccupation with accurate reproduction of previously learned words (Koriat, Goldsmith, \& Pansky, 2000). Today, however, there is a broad consensus among psychologists about the inherently constructive nature of episodic memory and its proneness to distortions. Two laboratory paradigms have contributed to this consensus (Dodhia \& Metcalfe, 1999; Mazzoni, 2002; Reyna, 2000). The first is the classic misleading information paradigm, in which participants are provided with misleading information about an event that they witnessed. When participants are later asked to recall the event,

\footnotetext{
* Corresponding author.

E-mail address: tom.smeets@psychology.unimaas.nl (T. Smeets).
} 
some of them will give false details on the basis of the misleading information. For example, in a study by Ackil and Zaragoza (1998), participants watched a movie fragment about boys at a summer camp showing one of the individuals tripping and falling. Next, the researchers suggested that that person was bleeding, although the video fragment had not shown this. When later asked where the individual was bleeding, some participants misremembered the suggested information as being accurate and gave detailed descriptions of where he was bleeding.

The second paradigm is the so-called false memory paradigm. In contrast to the misleading information paradigm, the false memory paradigm does not confront participants with misleading information. Here, false memories ${ }^{1}$ are said to result from participants' deductive inferences or internally created constructs that they subsequently mistake for externally experienced events (i.e., source monitoring errors, see Johnson, Hashtroudi, \& Lindsay, 1993; Lindsay, 1994). A good example of this approach is Bartlett's seminal study, where he had participants recount a story ("The War of the Ghosts"; see Bartlett, 1932) that was previously read to them. Due to their tendency to fill in memory gaps with internally generated schematic knowledge, participants changed or erroneously recalled certain details of the story (see for more recent examples, Bergman \& Roediger, 1999; Spiro, 1980).

Since the mid-1990s both approaches have attracted considerable attention from psychologists as well as a broader audience. This interest in false memory research was mainly fostered by a cascade of cases in which people, during the course of a psychotherapeutic treatment, suddenly came to "recover" what seem to be previously inaccessible memories of traumatic childhood events (e.g., sexual abuse). There are conflicting opinions about the accuracy of these recovered memories. Many clinicians believe that such memories are essentially accurate (e.g., Andrews et al., 1995; Van der Kolk \& Fisler, 1995). Other authors, among whom are experimental as well as clinical psychologists, have pointed out that recovered memories may reflect an iatrogenic effect. They argue that certain psychotherapeutic techniques (e.g., hypnosis, dream interpretation) may very well elicit fantasies and imaginations that are experienced as autobiographical memories (e.g., Loftus \& Ketcham, 1994; Ofshe \& Watters, 1994). By this view, recovering memories during therapy may be nothing more than the construction of false memories. The credibility of recovered memories has lead to a heated controversy between both positions, with each side imposing high standards of proof upon the other $\operatorname{side}^{2}$ (see, for a more thorough analysis, Read, 1999).

While the recovered memory debate is still inspiring extensive reviews (e.g., Brewin, 2003; McNally, 2003), both positions seem to have gotten closer to one another (Ost, 2003; Schooler, 1999). For example, many authors now acknowledge that false memories recovered during therapy do exist (Health Council of the Netherlands, 2004; Sivers, Schooler, \& Freyd, 2002) and that accurate memories that have long not been thought about may be experienced as recovered memories. One positive side-effect of the recovered memory debate is that it has given rise to a huge experimental literature on how certain manipulations may affect people's judgments about their memories. This, in turn, has informed clinicians about the potential risks of certain therapeutic interventions (e.g., hypnosis, imagination exercises, dream interpretation). However, some critics (e.g., Freyd \& Gleaves, 1996) have argued that generalizations from the experimental to the clinical context are difficult to make. Although points about

\footnotetext{
${ }^{1}$ We define false autobiographical memories or pseudo-memories as recollections of events that never happened or that are recalled very differently from how they actually happened. In this article, we use the popular term false memory rather than the more neutral term pseudomemory. We acknowledge, though, that false memory has negative connotations and that this has led to some terminological confusion.

2 Lindsay (1997, p. 1) refers to this as the "entrenchment effect".
} 
generalization problems are often somewhat gratuitous, we believe that these critics might be right in one important respect. In what follows, we critically discuss methods, results, and conclusions that one commonly encounters in the experimental literature on false memories. This shows us that - despite the diversity in methodologies and results - most authors interpret their results in terms of false memories. In doing so, they often employ the terms false memory and pseudo-memory in a rather loose way. Consequently, these terms are at risk of becoming of little substance. Our goal is to illustrate this point. It is not our intention to provide the reader with an exhaustive review of the false memory literature. Rather, we want to advocate a more disciplined use of key concepts like confidence, false belief, and false memory. That many current research papers use these terms in a liberal way, does not mean that we regard them as unimportant or irrelevant. Instead, we argue that as long as studies in this area do not address the definitional issue, there are limits to their applicability to real life situations (e.g., the courtroom).

\section{Neurotransmitters as a metaphor for false memories}

The term neurotransmitter was first used by the Austrian researcher Otto Loewi in 1921. It started a revolution in biology as many physiologists promptly concentrated their research on the identification and functioning of neurotransmitters. This resulted in a rapid expansion of publications in this area of research. The proliferation of the term neurotransmitter led researchers to consider virtually all substances in the human brain as neurotransmitters. To avoid that it would become meaningless, redefining the term neurotransmitter using stringent criteria was inevitable (Axelrod, 1974). Thus, for example, a candidate substance only attains neurotransmitter status when it can be shown that it is involved in physiologic transmission (Boehning \& Snyder, 2003). Not surprisingly, then, a considerable amount of research on putative neurotransmitters focuses on their consequences: do they affect postsynaptic transmission?

In contemporary research, the term false memory is used in a rather liberal way. For example, some studies deal with a belief in a fictitious event (i.e., a false belief). In some cases, even this interpretation is too generous because a confidence estimate of a particular event rather than a belief is the dependent variable. Conferring a memory status upon beliefs and confidence estimates is like treating every substance in the brain as a neurotransmitter. Our point is not new. For example, Sivers et al. (2002, p. 182) noted that: "Another concern regarding false memory studies involves the degree to which the ideas that individuals generate are best described as false memories. Many studies that have been characterized as involving the creation of false memories have not actually caused individuals to specifically recall events that never occurred but rather have caused them to believe [italics added] that such events might have occurred." Our impression is that the experimental literature on false memories has largely ignored differences between confidence estimates, beliefs, and memories. To some extent this has to do with difficulties in defining the key concept of memory. Thus, for example, the neuropsychologist Dimond (1980) viewed memory as a pervasive feature of the brain ranging from immunological reactions to autobiography. ${ }^{3}$

\footnotetext{
${ }^{3}$ Over the past two decades, the concept of memory has extended its scope to include not only autobiographical recollections, but also perceptual priming, Pavlovian conditioned responses, and so forth. Thus, the broad use of the term false memory has its origin in the broadened concept of 'memory' itself (e.g., Tulving, 2000).
} 


\section{Imagination}

Studies intending to examine false memories often rely on techniques such as imagination inflation (Garry, Manning, Loftus, \& Sherman, 1996), dream interpretation (Mazzoni, Loftus, Seitz, \& Lynn, 1999; Mazzoni, Lombardo, Malvagia, \& Loftus, 1999), and personalized suggestions (e.g., Hyman \& Billings, 1998; Hyman \& Pentland, 1996; Loftus \& Mazzoni, 1998; Porter, Yuille, \& Lehman, 1999). There are also studies that draw on real life situations. A case in point is the study by Crombag, Wagenaar, and van Koppen (1996), who used the 1992 El-Al airplane crash on Amsterdam as their starting point (see below). Whatever the technique, authors claim to investigate false memories, either explicitly (e.g., Garry \& Polascheck, 2000; Mazzoni \& Memon, 2003; Paddock et al., 1998) or by suggesting that the obtained results are pertinent to the recovered memory debate (e.g., Hyman \& Billings, 1998; Hyman \& Pentland, 1996; Mazzoni, Loftus, \& Kirsch, 2001).

Work on imagination inflation (e.g., Clancy, McNally, \& Schacter, 1999; Garry et al., 1996; Goff \& Roediger, 1998; Heaps \& Nash, 1999; Horselenberg et al., 2000; Mazzoni \& Memon, 2003; Paddock et al., 1998, 1999) offers examples of the terminological confusion that may arise. Here, participants are asked to fill out a Life Events Inventory (LEI; Garry et al., 1996), a questionnaire comprising 60 descriptions of certain events. Participants are asked to rate the probability that the events might have happened to them when they were a child. Sample items would be "Got in trouble for calling 911", "Broke a window with your hand", and "Won a stuffed animal at a carnival game". After one or two weeks, participants are asked to vividly imagine some of the situations that are described by the LEI items. Afterwards, participants are instructed to complete the LEI for a second time. Typically, researchers find that an event that was rated as unlikely increases in subjective probability after participants have imagined the event. Some authors argue that this imagination inflation effect tells us something about autobiographical memory distortions. For example, Paddock et al. (1998, p. S65) state that "[...] these results might provide insight into the mechanisms and processes by which false memories of childhood trauma may be created in psychotherapy." On a related note, Garry and Polascheck (2000, p. 6) opine that "A growing body of literature shows that imagining contrary-to-truth experiences can change memory [italics added]." Of course, these authors might be right. Yet, strictly speaking LEI items tap how confident participants are of having experienced a certain childhood event. They are not about having a detailed memory of that particular event.

Confidence is not the same as (false) memory. At most, inflated confidence constitutes a first step in the construction of false memories, just like L-DOPA is only a precursor of the neurotransmitter dopamine. Logically, it is perfectly possible to have inflated confidence without having false memories. More recent imagination inflation studies, like those by Mazzoni et al. (1999) or Mazzoni and Memon (2003) do not use the term false memory. Instead, these authors interpret their results in terms of false beliefs. In a recent review article, Loftus (2001, p. 585) pointed out that "Most of the studies of imagination inflation have shown shifts in belief, but have not explored whether actual memories or false memories accompany those shifts." However, given that imagination inflation studies rely on confidence estimates, even the term false belief may not always be justified. Suppose someone's confidence in a particular event (e.g., "Broke a window with your hand") increases from 1 to 3 on an 8point scale (anchors: 1 = definitely did not happen; 8 = definitely did happen) as a result of an imagination exercise. Does this person really belief that this specific event happened to him or her? We don't think so. This is not to say that an increase from 1 to 3 on the 8-point confidence scale is trivial. In fact, it is highly relevant to, for example, clinical interventions (e.g., cognitive therapy; see Rachman, 
2002; Radomsky, Rachman, \& Hammond, 2001) that intend to change the probability that clients attribute to certain events (e.g., not having a panic attack when entering a shop). But subjective probabilities are not the same as beliefs. In our opinion, it only makes sense to frame imagination inflation effects in terms of "belief" when confidence inflation is so large that it crosses the midpoint of the confidence scale. As far as we can see, only Heaps and Nash (1999) explicitly mention the differences between confidence, belief, and memory. Other authors summarize the results in this research domain in a way that does little justice to these differences. So, for example, Garry and Polascheck $(2000$; p. 8) say that "imagination can change autobiographies." Again, these authors might be right, but to date there is no imagination inflation study that fully documents this point. What can be said with some confidence, though, is that the effect of imagination not only inflates the confidence ratings of participants, but also undermines more fundamental memory processes. Thus, for example, Goff and Roediger (1998) found that imagining certain actions compromised the accuracy of source monitoring judgments (i.e., participants claimed to have performed rather than having imagined actions). Follow-up studies by Thomas and Loftus (2002) and Thomas, Bulevich, and Loftus (2003) indicate that these source monitoring errors persist even for actions that can be considered bizarre had they actually happened (e.g., kissing a magnifying glass).

\section{Suggestion}

Similar points can be raised about studies relying on dream interpretation or personalized suggestion. The first approach uses dream interpretation as the source of suggestion (e.g., Loftus \& Mazzoni, 1998; Mazzoni et al., 1999; Rassin, Merckelbach, \& Spaan, 2001; see also Pesant \& Zadra, 2004). Here, participants are asked to write down their recent dreams, on the basis of which the experimenter provides participants with suggestions about a childhood event that supposedly happened to them. Subsequently, the event is presented as the causal antecedent of their current dreams. Finally, participants have to rate their confidence in the suggested childhood event or have to provide memory reports on the event.

Another version of this approach uses suggestions embedded in hypnotic and non-hypnotic procedures to elicit certain information from participants (e.g., Spanos, Burgess, Burgess, Samuels, \& Blois, 1999; Spanos, Gwynn, Comer, Baltruweit, \& de Groh, 1989). Although these are well-designed studies that yielded highly interesting effects, they are sometimes very liberal in their terminology. For example, Mazzoni et al. (1999) say that participants showing an increase in LEI scores subsequent to dream interpretation held beliefs (p. 141) about the suggested events. This might be a problematic conclusion (cf. supra). The authors go even further when they state that about half of their experimentally manipulated participants also had memories (p. 142) of these events. This conclusion is based on a single question that participants answered: "Would you describe to me the memory you have for this event? Try to remember as much as you can, but please try to spend only three minutes on each question" (Mazzoni et al., 1999, p. 131). Next, two groups were formed: those who said to have memories of the events and those who did not. Participants were classified as having a memory of the event when "[...] subjects gave some indication [italics added] of having a memory" (Mazzoni et al., 1999, p. 137). Participants were classified as having no memory for the event when they "[...] actually wrote 'no memory', 'cannot remember this really happening', or something similar [italics added]" (Mazzoni et al., 1999, p. 137). Given this liberal way of defining memory reports, it remains to be seen whether the authors really succeeded in eliciting full-blown false memories. 
In experiments relying on personalized suggestions (e.g., Hyman \& Billings, 1998; Hyman, Husband, \& Billings, 1995; Hyman \& Pentland, 1996; Loftus \& Mazzoni, 1998; Wade, Garry, Read, \& Lindsay, 2002), information about a fictitious event (e.g., spilling a punch bowl at a wedding) is suggested to participants by claiming that the information was gathered from participants' parents or close relatives. The frequently cited experiments of Hyman and Billings (1998) and Hyman and Pentland (1996) tried to elicit false memories by using this type of personalized suggestion (for a more recent example, see Ost, Foster, Costall, \& Bull, in press). Participants were interviewed on several occasions about the suggested events and the researchers examined to what extent participants accepted the suggestions. Participants were eventually categorized in four groups. First, there was a "clear false memory" category containing participants, who said that they clearly remembered the particular event. These participants tried to complete their memories by providing progressively more details. Second, there was a "partial false memory" group of participants, who elaborated on the contextual details, but nevertheless said they had no specific memories of the incident. Thirdly, there was a group of participants, who tried to remember the incident, but said that they had no memories ("trying but no memory" group). Finally, there was a "no memory" group of participants, who essentially refused to attempt to recall information about the event. Using this classification format, Hyman and Pentland (1996) categorized 25\% of their participants as "clear false memory" as opposed to $12.5 \%$ "partial false memory", $62.5 \%$ "trying but no memory", and $0 \%$ "no memory".

Though Hyman and Pentland's (1996) criteria were more precise than those of many other authors, the question arises to what extent participants in the first category (i.e., the clear false memory group) really remembered the suggested fictitious event. Participants in this category came up with all sorts of new, probably inaccurate details, indicating that they believed that the fictitious event truly took place. But whether they actually remembered the details they came up with or whether they merely proposed them as a way of speculating about the event remains unclear. ${ }^{4}$ Schwarz (1999) pointed out that participants usually adopt a cooperative attitude. Even when researchers pose nonsensical questions to participants, there is always a subgroup of participants who provides an answer as a way of being helpful to the researchers. Specifically, Schwarz (1999, p. 96) noted that "From a conversational point of view, the sheer fact that a question about some issue is asked presupposes that the issue exists." Thus, one wonders to what extent the "clear false memory" participants in Hyman and Pentland's (1996) study tried to be helpful by presenting speculations as memories to the researchers.

\section{The El-Al crash}

Some authors have argued that suggestion may help create false memories for real life events. A study by Crombag et al. (1996) used a public event (i.e., the 1992 El-Al airplane crash) to find out whether people would claim to have memories of non-existing television scenes of this event. Thus, Crombag et al. sought to investigate their participants' memory for real television fragments of the El-Al Boeing 747 crashing into the buildings. To that end, the authors asked a simple forced choice (yes/no) question,

\footnotetext{
4 It is worthy of note that Hyman and Billings (1998) showed that false recalls obtained with their procedure were not related to participants' sensitivity to social demand. This is an important finding, but our point is, of course, broader. It may well be that most participants evaluated the experimental situation as a problem-oriented task and that some of them tried to be helpful by speculating about the fictitious event.
} 
namely "Did you see the television film of the moment the plane hit the apartment building?" (Crombag et al., 1996, p. 99). When answered affirmative, this was followed by one or more multiple choice questions, like "After the plane hit the building, there was a fire. How long did it take for the fire to start?" (Crombag et al., 1996, p. 99). Crombag et al. found that over half of their participants (55\% in study 1 and $66 \%$ in study 2) claimed to have seen the (non-existing) fragments. They speculated that the misleading suggestions embedded in their questions may have led their participants to come to believe that they saw a television fragment that in fact did not exist.

Because many participants gave detailed answers to the follow-up questions, Crombag et al. (1996, p. 102) also concluded that "[...] apparently these subjects had formed images [...]." In our view, the high percentage of participants claiming to have seen the film fragment does not necessarily mean that all of them actually had false memories or images. Another possibility is that participants, due to the highly suggestive context, drew upon general knowledge heuristics (e.g., "a plane crash causes an immediate explosion") rather than false memories when they answered the follow-up questions. As well, participants may have been eager to please the researchers and, hence, might have provided socially desirable answers without really believing them. In both cases, there is no need to postulate underlying false memories. ${ }^{5}$ In a highly similar study by Ost, Vrij, Costall, and Bull (2002), 44\% of the participants were willing to report that they had seen television fragments of the 1997 fatal crash of Diana, Princess of Wales, when in fact, no such film material exists. Interestingly, these authors found evidence that compliance (i.e., eagerness to please) may be a key factor in explaining why so many of their participants claimed to have seen the non-existing fragment. Ost et al. do not claim that their participants had developed false memories. In interpreting their findings, the authors are conservative in that they state that participants "claimed to have seen" (e.g., p. 132) the television fragment of Princess Diana's car crash.

\section{The story so far and its significance}

We may conclude, then, that experimental research on false memories is often vague and confusing when it comes to the point of whether effects exceed the level of weak or even strong beliefs. Of course, experimental work that shows how people can come to believe in fictitious events is fascinating and highly relevant. After all, there are patients who come to believe during therapy that they were the victim of childhood sexual abuse without ever having memories of these events (McNally, 2003; Ost, Costall, \& Bull, 2001; Ost, Costall, \& Bull, 2002). Indeed, these patients have much in common with patients who during therapy recover full-blown memories of being molested as children (McNally, 2003). For example, both groups are vulnerable to false alarms on recognition tasks (Clancy, Schacter, McNally \& Pitman, 2000) and, contrary to what many clinicians believe, are not particularly skilled in forgetting trauma-related words (McNally, Clancy, \& Schacter, 2001). Still, it is wise to differentiate between belief and memory. Germane to this issue is that McNally, Clancy, Schacter, and Pitman (2000) also noted subtle differences between patients with recovered memories of abuse and patients with beliefs about childhood abuse. For example, McNally et al. (2000) reported that patients who merely believed in that

\footnotetext{
5 Davis, Loftus, and Follette (2001, p. 151) noted that the study by Crombag et al. reflected false beliefs rather than false memories. They stated that "Clearly, these memories were nothing more than beliefs based on descriptions heard on T.V."
} 
they had been abused scored higher on measures of absorption and dissociation compared to patients with recovered memories of abuse, who in turn scored higher than patients who had always remembered their abuse.

Of course, false memories do exist. It would be foolish to deny that vivid memories of alien abduction episodes, held by some people who underwent hypnotic therapy, may be classified as false memories (Clancy, McNally, Schacter, Lenzenweger, \& Pitman, 2002). A similar line of reasoning applies to the detailed descriptions some people give of their memories of previous life experiences (Gomperts, 1996; Horselenberg \& Merckelbach, submitted for publication). But, sometimes there is a clear asymmetry between belief and memory. For example, in his work on "retractors" (i.e., people who retract their allegations of childhood sexual abuse), Ost (2003, p. 134) noted that with many of these individuals memory is simply not the issue: "One retractor reported that she believed for 11 years that she had been abused, yet never actually came to remember the abuse." Ost goes on to add: "When someone becomes convinced that a past event occurred whilst simultaneously claiming not to be able to remember that event, then factors other than 'a memory' were clearly crucial in her decision."

More parametric research focusing on the phenomenal experiences of people claiming alien abductions, previous lives or childhood sexual abuse is required, because it could give us better clues as to how to draw the demarcation lines between confidence, belief, and memory.

\section{Confidence estimates, false beliefs, and false memories}

Gardiner and Java (1993, p. 163) wrote that "The science of memory continues to be hampered by terminological confusion and excess. The same terms are often used to mean different things. Different terms are often used to mean the same things. Conceptual and theoretical progress would be easier if the use of terminology were to be reformed." We believe that their words bear relevance to false memory research. That is, this research domain would profit from stricter criteria for what counts as a false memory. A first step would be to make a distinction between confidence estimates about fictitious events, beliefs about such events, and false memories. Sporadically, authors do make this distinction. ${ }^{6}$ Johnson and Raye (2000, p. 36), for example, noted that "People tend to use the word 'memory" when a mental experience or report of a mental experience is detailed, including information indicating that one experienced the event oneself, and they tend to use the word 'belief' when it does not have contextual details and for a broad range of mental experiences or reports that seem to assert present or past general states of affairs which may or may not involve personally experienced events (including the events from which the belief was derived, such as reading a newspaper)." Likewise, Read and Lindsay (1994, p. 429) stated that "[...] some cases of inaccurate delayed accusations might be better characterized as involving false beliefs rather than illusory memories." In a similar vein, Ost (2003, p. 135) noted that "The problems arising from false claims and also incorrectly rejected claims of sexual abuse are not just about 'memory' as traditionally conceived and, in some cases, may have very little to do with 'memories' at all, whether 'false' or 'recovered'." Differentiating between belief and memory is also important to experimental investigators, as it may be much easier to elicit false

\footnotetext{
${ }^{6}$ Excellent chapters on the relationship between belief and memory of an event can be found in Schacter and Scarry (2000). On a minor point, also notice that Kopelman (1999) distinguishes between belief (delusions) and memory (delusional memory) among psychiatric patients.
} 
beliefs than false memories. Tulving (1985) argued that it is possible to distinguish between belief and memory on the basis of phenomenological experiences accompanying the retrieval of information. Thus, Tulving's remember-know distinction implies that if retrieval is accompanied by conscious recollection, participants experience a remember response. If, on the other hand, retrieval is accompanied by feelings of familiarity in the absence of conscious recollection, one is to speak of a know response (Gardiner \& Java, 1993; Tulving, 1985). Interestingly, some studies on false memories have collected direct remember-know judgments from their participants. For example, such data have been obtained in the context of the Deese-Roediger-McDermott paradigm (DRM; Deese, 1959; Roediger \& McDermott, 1995). Although this approach might be informative as it strikes the heart of the point we want to make, some authors have noted that participants not always find it easy to distinguish between remember and know judgments (e.g., Gardiner, Ramponi, \& Richardson Klavehn, 2002).

Several factors may modulate the confidence ratings that people give to particular childhood events. Among other factors, generic knowledge about the type of event (i.e., schematic knowledge), base rate of the event, fantasy proneness and suggestibility of the individual, and a lack of confidence in one's own memory ${ }^{7}$ may affect subjective likelihood estimates (e.g., Heaps \& Nash, 1999, Thomas et al., 2003). Whether one comes to believe the thought of having experienced a particular event depends to some extent on how plausible one judges the event to be (Hyman \& Kleinknecht, 1999; Loftus, 2003). If the prima facie plausibility is considered to be low, this will result in disbelief (denial of the thought). If, on the other hand, the subjective likelihood is judged to be high, one will often start to believe in and become convinced of actually having experienced the event. Germane to this issue is the finding of Pezdek, Finger, and Hodge (1997) that highly plausible events (e.g., getting lost in a shopping mall) were more likely to be endorsed by their participants than less plausible events (e.g., having a rectal enema). Note that research also suggests that familiarity and plausibility are not static qualities. Thus, work by Goff and Roediger (1998) and Thomas and Loftus (2002) indicates that with multiple acts of imagination, people can be led to believe that they performed an unusual action (e.g., sit on a dice).

\section{Models}

Over the past 10 years or so, several models have been invoked to account for the development of false beliefs and false memories (e.g., Hyman \& Kleinknecht, 1999; Mazzoni \& Kirsch, 2002; Tousignant, Hall, \& Loftus, 1986). One of the first attempts was that by Tousignant et al. (1986); also see Schooler \& Loftus, 1986) and involved a principle known as Discrepancy Detection. According to this principle, "Recollections are most likely to change if a person does not immediately detect discrepancies between post-event suggestions and memory for the original event" (Schooler \& Loftus, 1986, p. 107108). Discrepancy detection is assumed to be influenced by two factors: (1) the strength of the information that was originally encoded, and (2) the manner in which the post-event suggestion was presented to the participant. ${ }^{8}$ The implication of this is that (partial) amnesia is a necessary condition for the development of a full-blown false autobiographical memory.

\footnotetext{
7 This phenomenon, in which people come to doubt the quality of their own memory, is known as the memory distrust syndrome (Gudjonsson \& MacKeith, 1982).

${ }^{8}$ A more recent version of the discrepancy detection principle can be found in Lindsay (1990), who in this context wrote about the discrimination hypothesis.
} 
More recently, Hyman and Kleinknecht (1999; see also Hyman \& Loftus, 1998) argued that the development of false (childhood) memories involves three processes: event acceptance (plausibility assessment), memory construction, and a source monitoring error. First, a person has to judge the suggested event as plausible. That is, the person should believe that the event could have happened. Factors that may have an effect on the plausibility assessment are the source of the suggestion, the nature of the event itself, and the likelihood of having personally experienced a similar event. Second, apart from believing that the suggested event is likely to have happened, a person "[ . . ] must still construct a memory - an image with a narrative" (Hyman \& Kleinknecht, 1999, p. 180). Finally, one must misinterpret the constructed memory as an autobiographical memory. Thus, one has to make a source monitoring error and mistakenly claim the memory for an authentic personal memory. According to Hyman and Kleinknecht (1999, p. 181), “[...] all three processes are necessary for false memory creation and [that they] are somewhat independent in the sense that different factors influence each process."

A somewhat different conceptualization of false memories has recently been proposed by Mazzoni and Kirsch (2002). Although these authors noted that their model is in many ways consistent with that of Hyman and Kleinknecht (1999), they also point at one major discrepancy between both models. Thus, Mazzoni and Kirsch's (2002) model distinguishes between belief and memory. More specifically, these authors emphasize that autobiographical beliefs involve judgments about specific events, which guide the search for memories (i.e., recollective experiences).

With these models in mind, one could describe the various key concepts in this research domain as follows. Subjective probability (likelihood) of an event refers to a subjective estimate of the probability that the event reflects a genuinely experienced event. In line with Koehler (1991), one's overt expression of the subjective probability of a particular event is what we term confidence. A belief, on the other hand, emerges when one's confidence in the reality of an event is strong enough as to have little doubt about the veracity of the event. In that case, one comes to believe that one has experienced a certain event. This is primarily derived from other knowledge. Of course, beliefs may vary in strength and they may be true or false. When one believes in the veracity of a particular event and one has a concrete, narrative, episodic recollection together with an image of the event, one can speak of a memory of the event. Again, a memory can be true or false.

\section{Behavioral sequence}

Some authors fail to articulate the distinction between false belief and false memory. For example, Lampinen, Neuschatz, and Payne (1998, p.182) define false memories as "[...] false beliefs about the past that are experienced as memories." Yet, in our opinion, false memories are more than just plain beliefs. That is, if people remember something happening, they will be likely to believe that it happened. However, believing in one's birth is not the same as having a memory of it (Mazzoni \& Kirsch, 2002). Moreover, not every belief or memory is of equal significance. A particular belief or memory is of demonstrable significance only when a person acts on it. Following the pragmatic tradition that considers memory in the service of overt behavior (e.g., Fiske, 1992; Neisser, 1996), one could take the stance that the significance of a belief or memory can be derived from its behavioral sequence. This sequence can vary from passing the false information on to others (e.g., a confederate of the experiment), searching for additional information by talking to family or friends, or, in the case of a false confession, 
accepting a conviction. The recovered-false memory debate was, of course, fuelled by high publicity cases in which patients took legal action on the basis of their recovered memories. This leads us to conclude that the strongest demonstration of an experimentally induced false memory would be one in which participants not only come up with detailed reports about the false event, but also act on the basis of these reports. We are not alone in this conclusion. Thus, having discussed a new experimental approach in which imagination inflation was found to contribute to people's food aversion, Loftus (2003, p. 870) recently concluded that "One might then be able to show that false memories have consequences, that they do matter."

Recent work by Scoboria, Mazzoni, Kirsch, and Relyea (2004) suggests that confidence, false beliefs, and false memories can best be viewed as nested constructs. That is, having a memory of an event generally implies a belief that the event happened and, likewise, having autobiographical belief generally implies that the event is seen as plausible. However, if someone rates the probability of a certain event low or, for that matter, beliefs in the event, but shows no memory of it, this is not necessarily an end stage. When elaborating about a fictitious event, for example during therapy sessions in which imagination or hypnosis is repeatedly used, one's confidence in the event might increase. With more sessions, one may then shift from disbelief to belief that the false event has happened and eventually, one might shift from believing to actually constructing a false memory about a fictitious event. In current research on imagination inflation, several studies have found evidence that familiarity rather than reality monitoring failures drive the imagination inflation effect (e.g., Thomas et al., 2003). Perhaps, then, familiarity with the false event precedes increases in confidence and upward shifts in belief, while reality monitoring failures precede full-blown false memories. Moreover, response criterion ${ }^{9}$ shifts may be responsible for changing from disbelief to belief. An example might clarify this. Suppose that during the course of a treatment session, the therapist exposes his/her patient to the suggestion that childhood trauma is the source of the patient's current complaints. Possibly, the patient will put his or her trust in the therapist. As a result, the patient may come to believe that he or she was a victim of childhood sexual abuse. At that point, however, the patient need not have any memories of the abuse. As time passes and after elaborating on the issue of abuse (e.g., with regression therapy or imagination exercises), clear, vivid, and detailed images of the abuse may emerge. However, only when the patient acts upon the basis of these images, like seeking confirmation from possible witnesses or confronting the alleged perpetrator, it becomes apparent that the patient takes his/her recovered images as real memories.

\section{Anxiety research}

Of course, there is no need for behavioral consequences to be exclusively related to memories. That is, one may act on the mere basis of a firmly held belief that does not possess any mnemonic qualities. Evidence for this comes from anxiety research on a cognitive bias termed Thought-Action Fusion (TAF; e.g., Rachman, 1993; Rachman \& Shafran, 1999) and from experimental work on indirect pathways to fear acquisition (e.g., Field, Argyris, \& Knowles, 2001; Field \& Lawson, 2003). Rachman (1993), Rachman and Shafran (1999), and Shafran, Thordarson, and Rachman (1996) have identified a cognitive

\footnotetext{
9 The consideration of how accurate information has to be judged in order for it to be reported. Mazzoni and Kirsch (2002) call this the pre-set criterion probability.
} 
distortion that is apparent in patients with Obsessive Compulsive Disorder (OCD). This cognitive distortion (TAF) refers to a bias that may increase people's sense of responsibility for their intrusive thoughts and, hence, can be regarded as a vulnerability factor for the development of clinical obsessions (e.g., Rachman \& Shafran, 1999; Rassin, Merckelbach, Muris, \& Spaan, 1999). TAF involves two separate components: probability and moral TAF. Probability TAF refers to OCD patients' tendency to believe that their intrusive thoughts increase the probability that a specific negative event will occur. Thus, OCD patients assume that having intrusive thoughts about, say, their parents suffering from an illness, will increase the probability that this will happen. Moral TAF refers to the belief that experiencing an intrusive thought (e.g., about an aggressive act) is morally equivalent to actually carrying out the prohibited action. There is ample evidence that OCD patients give high probability ratings for negative events as a result of their negative thoughts (e.g., Shafran et al., 1996; Amir, Freshman, Ramsey, Neary, \& Brigidi, 2001). Thus, these patients believe they can be held responsible for the anticipated negative event and this motivates them to engage in compulsive checking behavior (e.g., Rachman, 2002). Clearly, these checking behaviors are based on the patients' sheer beliefs that they are responsible for future events.

Interestingly, Ladouceur et al. (1995; experiment 2) demonstrated that beliefs about responsibility affect checking behaviors. Thus, Ladouceur et al. had their participants sort 200 pills (medication for a deadly virus) of 10 different color combinations (20 capsules of each color) that were initially placed in a bowl. Participants were instructed to put the pills in semi-transparent bottles, and were either told that this was merely a pilot test (low responsibility group) or that their test performance would have a great and immediate impact (e.g., on the distribution of pills among poor people for which a wrong combination of colors could have lethal consequences). Compared to low responsibility participants, the high responsibility group exhibited a stronger preoccupation with errors and they experienced more subjective anxiety to make errors. More importantly, participants in the high responsibility group showed stronger hesitations in sorting the pills and they more often engaged in checking behaviors.

Another good example of behavior associated with pure belief (i.e., without memory) can be found in the experimental work of Field et al. (2001) and Field and Lawson (2003). In two experiments, Field et al. (2001) provided children aged 7 through $9(N=40$ and $N=45$, respectively) with either positive (e.g., "very friendly") or negative (e.g., "very dangerous") information about toy monsters that were completely new to the children. Field et al. found that children showed increased scores on a fear-belief questionnaire concerning the monster about which they had received the negative information. In a subsequent study using Australian marsupials (i.e., the quoll, quokka, and cuscus) that were unfamiliar to the participants, Field and Lawson (2003) presented 6 to 9 year olds $(N=59)$ with negative, positive or neutral information about the animals. Not only did negative information significantly increase children's fear beliefs (measured by self-report and implicit measures of the belief), but it also elicited avoidance behavior. That is, children were more reluctant to approach a box which they believed contained the animal they had previously received negative information about. Evidently, increased fear beliefs were the antecedent of this behavioral consequence.

\section{A look at future research}

Experiments in the domain of anxiety research offer inspiring examples of how one can address the behavioral consequences of beliefs and memories. This is important because only a handful of studies 
concerned with false memories looked at the potential consequences of false recollections. An example may help to explain why it is informative to look at behavioral consequences. Suppose an individual has been ripped off for hundreds of dollars in purchasing a new car. When buying another vehicle, he/she will probably not go to the same car seller again. This, of course, has to do with remembering the bad investment. If, on the other hand, the individual sees it only as a remote possibility that the car seller has sold bad cars, he/she may very well visit the car seller for a second time. So, the behavior of the individual tells us something about his/her beliefs or memories about the car seller.

Consider this hypothetical experiment. Suppose that participants would imagine having experienced a traumatic childhood incident with a spider. Would they react with phobic anxiety when exposed to a spider? ${ }^{10}$ Or suppose one would tell participants that their dreams mean that as a child, they became nauseous each time they ate cereals for breakfast. Would that lead to these participants start to avoid eating cereals? As a matter of fact, Loftus (2003) recently found some tentative evidence that these consequences can, indeed, be elicited with typical false memory manipulations. When Alan Alda ${ }^{11}$ visited Loftus for television recordings, he completed a number of questionnaires about his food preferences, eating habits, and his personality (Loftus, 2003). During a follow-up session, Alda was told that an analysis of the questionnaires had revealed that he had an aversion to hard-boiled eggs. Loftus and her research associates tried to convince Alda that as a child, he must have gotten sick after eating too many hard-boiled eggs. They succeeded, because after a while, Alda increasingly showed behavioral signs of believing in the authenticity of the fabricated story. During a picnic, Alda was offered a few hard-boiled eggs amongst other foods. Alda refused to eat the eggs. Of course, Alda's reluctance to eat the hard-boiled eggs may be due to a number of causes, but the example demonstrates how one might examine the behavioral consequences of false beliefs and false memories.

One research line that has explicitly focused on behavioral consequences of false beliefs and false memories is that concerned with false confessions. Kassin and Kiechel's (1996) classic study showed that it is relatively easy to obtain false confessions of healthy undergraduates. These authors instructed their participants to copy letters that were presented on a computer screen. Participants were told not to touch the Alt-key because otherwise the computer would crash. During the task, the computer did crash and participants were falsely accused of having touched the forbidden key. Next, participants were asked to sign a written confession and they were approached by a confederate of the experiment who acted as a naïve subject. This confederate asked the participant about what happened. Kassin and Kiechel found that many participants (depending on the precise conditions between $35 \%$ and $100 \%$ ) were willing to sign a written confession. A smaller portion of them (depending on the conditions between $0 \%$ and $65 \%$ ) related to the confederate how they had touched the forbidden Alt-key. At the very least, this suggests that these participants firmly believed that they had touched the forbidden key. That is, they had internalized the false confession.

A replication study by Horselenberg, Merckelbach, and Josephs (2003) explored whether false confessions would manifest themselves in more far-reaching behavioral consequences. Following a procedure that was similar to that of Kassin and Kiechel, these authors investigated whether their falsely accused participants would accept a negative consequence of confessing, in this case paying a considerable amount of money. The results of Horselenberg et al. indicate that especially those

\footnotetext{
10 This issue is currently under investigation in our laboratory.

11 Alan Alda is the host of Scientific American Frontiers, a popular American t.v. show, and is widely known from his role as Hawkeye Pierce in the classic t.v. series $M^{*} A^{*} S^{*} H$.
} 
participants who showed signs of internalization (42\% of all participants) were willing to pay. A followup study by Horselenberg et al. (in press) shows that even when event plausibility is low and stakes are high (e.g., being falsely accused of exam fraud), some undergraduates falsely confess. Redlich and Goodman (2003) recently investigated whether children aged 12 and $13(N=32)$, children aged 15 and $16(N=32)$, and young adults aged 18-26 $(N=32)$ were willing to accept a highly aversive consequence of falsely confessing, namely returning for approximately $10 \mathrm{~h}$ and reenter the lost data. These authors found that, on average, $69 \%$ of their participants falsely confessed to hitting the forbidden key and, thus, were willing to accept the negative consequence. In our view, this type of approach offers good examples of how one may study the behavioral manifestations of firmly held misinterpretations (false beliefs) and false memories. ${ }^{12}$

Paying systematic attention to the behavioral consequences of false beliefs and false memories will enable us to formulate more fine graded models on how confidence may develop into beliefs and memories. Apart from theoretical issues, there is one practical reason for focusing on overt behavioral consequences of memory manipulations. As already noted, one key issue in recovered memories is that people who have them are so convinced of their accuracy that they act on the basis of their memories (e.g., by filing a lawsuit or by confronting family members). The parallel between laboratory experiments and real life examples of recovered memories will become much more compelling if these experiments involve overt behavior (e.g., avoiding cues, signing a confession, talking to a confederate) that only makes sense when it is assumed that the actor holds firm beliefs or has detailed memories that he/she believes to be accurate.

\section{Acknowledgements}

The authors would like to thank two anonymous reviewers for their helpful comments and suggestions. This review was supported by the Netherlands Organization for Scientific Research (NWO) grant 452-02-006 awarded to Dr. Marko Jelicic.

\section{References}

Ackil, J. K., \& Zaragoza, M. S. (1998). Memorial consequences of forced confabulation: Age differences in susceptibility to false memories. Developmental Psychology, 34, 1358-1372.

Amir, N., Freshman, M., Ramsey, B., Neary, E., \& Brigidi, B. (2001). Thought-action fusion in individuals with OCD symptoms. Behaviour Research and Therapy, 39, 765-776.

Andrews, B., Morton, J., Bekerian, D. A., Brewin, C. R., Davies, G. M., \& Mollon, P. (1995). The recovery of memories in clinical practice: Experiences and beliefs of British Psychological Society practitioners. Psychologist, 8, $209-214$.

Axelrod, J. (1974). Neurotransmitters. Scientific American, 230, 59-71.

Bartlett, F. C. (1932). Remembering: A study in experimental and social psychology. Oxford, England: Macmillan.

Bergman, E. T., \& Roediger III, H. L. (1999). Can Bartlett's repeated reproduction experiments be replicated? Memory \& Cognition, 27, 937-947.

Boehning, D., \& Snyder, S. H. (2003). Novel neural modulators. Annual Review of Neuroscience, 26, $105-131$.

\footnotetext{
12 An interesting parallel between false confessions and false memories can also be found in Ost et al. (2001). For a rationale on how false confessors can come to believe they are guilty and subsequently create false memories supporting those beliefs, see Henkel and Coffman (2004).
} 
Brewin, C. R. (2003). Posttraumatic stress disorder: Malady or myth?. New Haven, CT: Yale University Press.

Clancy, S. A., McNally, R. J., \& Schacter, D. L. (1999). Effects of guided imagery on memory distortion in women reporting recovered memories of childhood sexual abuse. Journal of Traumatic Stress, 12, 559-569.

Clancy, S. A., McNally, R. J., Schacter, D. L., Lenzenweger, M. F., \& Pitman, R. K. (2002). Memory distortion in people reporting abduction by aliens. Journal of Abnormal Psychology, 111, 455-461.

Clancy, S. A., Schacter, D. L., McNally, R. J., \& Pitman, R. K. (2000). False recognition in women reporting recovered memories of sexual abuse. Psychological Science, 11, 26-31.

Crombag, H. F. M., Wagenaar, W. A., \& van Koppen, P. J. (1996). Crashing memories and the problem of "source monitoring". Applied Cognitive Psychology, 10, 95-104.

Davis, D., Loftus, E. F., \& Follette, W. C. (2001). Commentary on "Standards for informed consent in recovered memory therapy": How, when, and whether to use informed consent for recovered memory therapy. Journal of the American Academy of Psychiatry and the Law, 29, 148-159.

Deese, J. (1959). On the prediction of occurrence of particular verbal intrusions in immediate recall. Journal of Experimental Psychology, 58, 17-22.

Dimond, S. J. (1980). Neuropsychology. A textbook of systems and psychological functions of the human brain. London: Butterworth.

Dodhia, R. M., \& Metcalfe, J. (1999). False memories and source monitoring. Cognitive Neuropsychology, 16, 489-508.

Field, A. P., Argyris, N. G., \& Knowles, K. A. (2001). Who's afraid of the big bad wolf: A prospective paradigm to test Rachman's indirect pathways in children. Behaviour Research and Therapy, 39, 1259-1276.

Field, A. P., \& Lawson, J. (2003). Fear information and the development of fears during childhood: Effects on implicit fear responses and behavioural avoidance. Behaviour Research and Therapy, 41, 1277-1293.

Fiske, S. T. (1992). Thinking is for doing: Portraits of social cognition from Daguerreotype to laserphoto. Journal of Personality and Social Psychology, 63, 877-889.

Freyd, J. J., \& Gleaves, D. H. (1996). "Remembering" words not presented in lists: Relevance to the current recovered/false memory controversy. Journal of Experimental Psychology: Learning, Memory, and Cognition, 22, 811-813.

Gardiner, J. M., \& Java, R. I. (1993). Recognising and remembering. In A. F. Collins, \& S. E. Gathercole (Eds.), Theories of memory (pp. 163-188). Hillsdale: Lawrence Erlbaum Associates Inc.

Gardiner, J. M., Ramponi, C., \& Richardson Klavehn, A. (2002). Recognition memory and decision processes: A meta-analysis of remember, know, and guess responses. Memory, 10, 83-98.

Garry, M., Manning, C. G., Loftus, E. F., \& Sherman, S. J. (1996). Imagination inflation: Imagining a childhood event inflates confidence that it occurred. Psychonomic Bulletin and Review, 3, 208-214.

Garry, M., \& Polascheck, D. L. L. (2000). Imagination and memory. Current Directions in Psychological Science, 9, 6-10.

Goff, L. M., \& Roediger III, H. L. (1998). Imagination inflation for action events: Repeated imaginings lead to illusory recollections. Memory \& Cognition, 26, 20-33.

Gomperts, W. (1996). Herinneringen aan het hiervoormaals [Memories of past lives]. Maandblad Geestelijke Volksgezondheid [Monthly Journal of Public Mental Health], 7/8, 777-800.

Gudjonsson, G. H., \& MacKeith, J. A. C. (1982). False confessions: Psychological effects of interrogation. A discussion paper. In A. Trankell (Ed.), Reconstructing the past: The role of psychologists in criminal trials (pp. 253-269). Deventer: Kluwer.

Health Council of the Netherlands (2004). Disputed memories. The Hague: Health Council of the Netherlands Publication no. 2004/02.

Heaps, C., \& Nash, M. (1999). Individual differences in imagination inflation. Psychonomic Bulletin and Review, 6, 313-318.

Henkel, L. A., \& Coffman, K. J. (2004). Memory distortions in coerced false confessions: A source monitoring framework analysis. Applied Cognitive Psychology, 18, 567-588.

Horselenberg, R., \& Merckelbach, H. (submitted for publication). Fantasy proneness and dissociative experiences in adults with previous-life memories.

Horselenberg, R., Merckelbach, H., \& Josephs, S. (2003). Individual differences and false confessions: A conceptual replication of Kassin and Kiechel (1996). Psychology, Crime \& Law, 9, 1-8.

Horselenberg, R., Merckelbach, H., Muris, P., Rassin, E., Sijsenaar, M., \& Spaan, V. (2000). Imagining fictitious childhood events: The role of individual differences in imagination inflation. Clinical Psychology and Psychotherapy, 7, 128-137.

Horselenberg, R., Merckelbach, H., Smeets, T., Franssens, D., Peters, G. J. Y., \& Zeles, G. (in press). False confessions in the lab: Do plausibility and consequences matter? Psychology, Crime \& Law.

Hyman, I. E. J., \& Billings, F. J. (1998). Individual differences and the creation of false childhood memories. Memory, 6, 1-20. 
Hyman, I. E. J., Husband, T. H., \& Billings, F. J. (1995). False memories of childhood experiences. Applied Cognitive Psychology, 9, 181-197.

Hyman, I. E. J., \& Kleinknecht, E. E. (1999). False childhood memories: Research, theory, and applications. In L. M. Williams, \& V. L. Banyard (Eds.), Trauma and memory (pp. 175-188). Thousand Oaks, CA, US: Sage Publications Inc.

Hyman Jr., I. E., \& Loftus, E. F. (1998). Errors in autobiographical memory. Clinical Psychology Review, $18,933-947$.

Hyman, I. E. J., \& Pentland, J. (1996). The role of mental imagery in the creation of false childhood memories. Journal of Memory and Language, 35, 101-117.

Johnson, M. K., Hashtroudi, S., \& Lindsay, D. S. (1993). Source monitoring. Psychological Bulletin, 114, 3-28.

Johnson, M. K., \& Raye, C. L. (2000). Cognitive and brain mechanisms of false memories and beliefs. In D. L. Schacter (Ed.), Memory, brain, and belief (pp. 35-86). Cambridge, MA: Harvard University Press.

Kassin, S. M., \& Kiechel, K. L. (1996). The social psychology of false confessions: Compliance, internalization, and confabulation. Psychological Science, 7, 125-128.

Koehler, D. J. (1991). Explanation, imagination, and confidence in judgment. Psychological Bulletin, 110, $499-519$.

Kopelman, M. D. (1999). Varieties of false memory. Cognitive Neuropsychology, 16, 197-214.

Koriat, A., Goldsmith, M., \& Pansky, A. (2000). Toward a psychology of memory accuracy. Annual Review of Psychology, 51, 481-537.

Ladouceur, R., Rheaume, J., Freeston, M. H., Aublet, F., Jean, K., Lachance, S., et al. (1995). Experimental manipulations of responsibility: An analogue test for models of obsessive-compulsive disorder. Behaviour Research and Therapy, 33, 937-946.

Lampinen, J. M., Neuschatz, J. S., \& Payne, D. G. (1998). Memory illusions and consciousness: Examining the phenomenology of true and false memories. Current Psychology: Developmental, Learning, Personality, Social, 16, $181-224$

Lindsay, D. S. (1990). Misleading suggestions can impair eyewitnesses' ability to remember event details. Journal of Experimental Psychology: Learning, Memory, and Cognition, 16, 1077-1083.

Lindsay, D. S. (1994). Memory source monitoring and eyewitness testimony. In D. F. Ross, \& J. D. Read (Eds.), Adult eyewitness testimony: Current trends and developments (pp. 27-55). New York, NY: Cambridge University Press.

Lindsay, D. S. (1997). Increasing sensitivity. In J. D. Read, \& D. S. Lindsay (Eds.), Recollections of trauma: Scientific evidence and clinical practice (pp. 1-16). New York: Plenum Press.

Loftus, E. F. (2001). Imagining the past. Psychologist, 14, 584-587.

Loftus, E. F. (2003). Make-believe memories. American Psychologist, 58, 867-873.

Loftus, E. F., \& Ketcham, K. (1994). The myth of repressed memory: False memories and allegations of sexual abuse. New York: St. Martin's Press.

Loftus, E. F., \& Mazzoni, G. A. L. (1998). Using imagination and personalized suggestion to change people. Behavior Therapy, 29, 691-706.

Mazzoni, G. (2002). Naturally occurring and suggestion-dependent memory distortions: The convergence of disparate research traditions. European Psychologist, 7, 17-30.

Mazzoni, G., \& Kirsch, I. (2002). Autobiographical memories and beliefs: A preliminary metacognitive model. In T. J. Perfect, \& B. L. Schwartz (Eds.), Applied metacognition (pp. 121-146). Cambridge, UK: Cambridge University Press.

Mazzoni, G. A. L., Loftus, E. F., \& Kirsch, I. (2001). Changing beliefs about implausible autobiographical events: A little plausibility goes a long way. Journal of Experimental Psychology. Applied, 7, 51-59.

Mazzoni, G. A. L., Loftus, E. F., Seitz, A., \& Lynn, S. J. (1999). Changing beliefs and memories through dream interpretation. Applied Cognitive Psychology, 13, 125-144.

Mazzoni, G. A. L., Lombardo, P., Malvagia, S., \& Loftus, E. F. (1999). Dream interpretation and false beliefs. Professional Psychology, Research and Practice, 30, 45-50.

Mazzoni, G., \& Memon, A. (2003). Imagination can create false autobiographical memories. Psychological Science, 14, $186-188$.

McNally, R. J. (2003). Remembering trauma. Cambridge, MA: Belknap Press/Harvard University Press.

McNally, R. J., Clancy, S. A., \& Schacter, D. L. (2001). Directed forgetting of trauma cues in adults reporting repressed or recovered memories of childhood sexual abuse. Journal of Abnormal Psychology, 110, 151-156.

McNally, R. J., Clancy, S. A., Schacter, D. L., \& Pitman, R. K. (2000). Personality profiles, dissociation, and absorption in women reporting repressed, recovered, or continuous memories of childhood sexual abuse. Journal of Consulting and Clinical Psychology, 68, $1033-1037$. 
Neisser, U. (1996). Remembering as doing. Behavioral and Brain Sciences, 19, 203-204.

Ofshe, R., \& Watters, E. (1994). Making monsters: False memories, psychotherapy, and sexual hysteria. New York: Charles Scribner's Sons/MacMillan Publishing Co.

Ost, J. (2003). Seeking the middle ground in the 'memory wars'. British Journal of Psychology, 94, 125-139.

Ost, J., Costall, A., \& Bull, R. (2001). False confessions and false memories: A model for understanding retractors' experiences. Journal of Forensic Psychiatry, 12, 549-579.

Ost, J., Costall, A., \& Bull, R. (2002). A perfect symmetry? Retractors' experiences of recovering and retracting abuse memories. Psychology, Crime \& Law, 8, 155-181.

Ost, J., Foster, S. Costall, A., \& Bull, R. (in press). False reports of childhood events in appropriate interviews. Memory.

Ost, J., Vrij, A., Costall, A., \& Bull, R. (2002). Crashing memories and reality monitoring: Distinguishing between perceptions, imaginations, and 'false memories'. Applied Cognitive Psychology, 16, 125-134.

Paddock, J. R., Joseph, A. L., Chan, F. M., Terranova, S., Manning, C. G., \& Loftus, E. F. (1998). When guided visualization procedures may backfire: Imagination inflation and predicting individual differences in suggestibility. Applied Cognitive Psychology, 12, S63-S75.

Paddock, J. R., Noel, M., Terranova, S., Eber, H. W., Manning, C., \& Loftus, E. F. (1999). Imagination inflation and the perils of guided visualization. Journal of Psychology, 133, 581-595.

Pesant, N., \& Zadra, A. (2004). Working with dreams in therapy: What do we know and what should we do? Clinical Psychology Review, 24, 489-512.

Pezdek, K., Finger, K., \& Hodge, D. (1997). Planting false childhood memories: The role of event plausibility. Psychological Science, 8, 437-441.

Porter, S., Yuille, J. C., \& Lehman, D. R. (1999). The nature of real, implanted, and fabricated memories for emotional childhood events: Implications for the recovered memory debate. Law and Human Behavior, 23, 517-537.

Rachman, S. (1993). Obsessions, responsibility, and guilt. Behaviour Research and Therapy, 31, 149-154.

Rachman, S. (2002). A cognitive theory of compulsive checking. Behaviour Research and Therapy, 40, 624-639.

Rachman, S., \& Shafran, R. (1999). Cognitive distortions: Thought-action fusion. Clinical Psychology and Psychotherapy, 6, $80-85$.

Radomsky, A. S., Rachman, S., \& Hammond, D. (2001). Memory bias, confidence and responsibility in compulsive checking. Behaviour Research and Therapy, 39, 813-822.

Rassin, E., Merckelbach, H., Muris, P., \& Spaan, V. (1999). Thought-action fusion as a causal factor in the development of intrusions. Behaviour Research and Therapy, 37, 231-237.

Rassin, E., Merckelbach, H., \& Spaan, V. (2001). When dreams become a royal road to confusion: Realistic dreams, dissociation, and fantasy proneness. Journal of Nervous and Mental Disease, 189, 478-481.

Read, J. D. (1999). The recovered/false memory debate: Three steps forward, two steps back? Expert Evidence, 7, 1-24.

Read, J. D., \& Lindsay, D. S. (1994). Moving toward a middle ground on the "false memory debate": Reply to commentaries on Lindsay and Read. Applied Cognitive Psychology, 8, 407-435.

Redlich, A. D., \& Goodman, G. S. (2003). Taking responsibility for an act not committed: The influence of age and suggestibility. Law and Human Behavior, 27, 141-156.

Reyna, V. F. (2000). Fuzzy-trace theory and source monitoring: An evaluation of theory and false-memory data. Learning and Individual Differences, 12, 163-175.

Roediger III, H. L., \& McDermott, K. B. (1995). Creating false memories: Remembering words not presented in lists. Journal of Experimental Psychology: Learning, Memory, and Cognition, 21, 803-814.

Schacter, D. L., \& Scarry, E. (2000). Memory, brain, and belief. Cambridge, MA: Harvard University Press.

Schooler, J. W. (1999). Seeking the core: The issues and evidence surrounding recovered accounts of sexual trauma. In L. M. Williams (Ed.), Trauma and memory (pp. 203-216). Thousand Oaks, CA: Sage Publications.

Schooler, J. W., \& Loftus, E. F. (1986). Individual differences and experimentation: Complementary approaches to interrogative suggestibility. Social Behaviour, 1, 105-112.

Schwarz, N. (1999). Self-reports: How the questions shape the answers. American Psychologist, 54, 93-105.

Scoboria, A., Mazzoni, G., Kirsch, I., \& Relyea, M. (2004). Plausibility and belief in autobiographical memory. Applied Cognitive Psychology, 18, 791-807.

Shafran, R., Thordarson, D. S., \& Rachman, S. (1996). Thought-action fusion in obsessive compulsive disorder. Journal of Anxiety Disorders, 10, 379-391.

Sivers, H., Schooler, J., \& Freyd, J. J. (2002). Recovered memories. Encyclopedia of the Human Brain, 4, 169-184. 
Spanos, N. P., Burgess, C. A., Burgess, M. F., Samuels, C., \& Blois, W. O. (1999). Creating false memories of infancy with hypnotic and non-hypnotic procedures. Applied Cognitive Psychology, 13, 201-218.

Spanos, N. P., Gwynn, M. I., Comer, S. L., Baltruweit, W. J., \& de Groh, M. (1989). Are hypnotically induced pseudomemories resistant to cross-examination? Law and Human Behavior, 13, 271-289.

Spiro, R. J. (1980). Accommodative reconstruction in prose recall. Journal of Verbal Learning and Verbal Behavior, 19, 84-95.

Thomas, A. K., Bulevich, J. B., \& Loftus, E. F. (2003). Exploring the role of repetition and sensory elaboration in the imagination inflation effect. Memory \& Cognition, 31, 630-640.

Thomas, A. K., \& Loftus, E. F. (2002). Creating bizarre false memories through imagination. Memory \& Cognition, 30, 423-431.

Tousignant, J. P., Hall, D., \& Loftus, E. F. (1986). Discrepancy detection and vulnerability to misleading postevent information. Memory \& Cognition, 14, 329-338.

Tulving, E. (1985). Memory and consciousness. Canadian Psychology, 26, 1-12.

Tulving, E. (2000). Concepts of memory. In E. Tulving, \& F. I. M. Craik (Eds.), The Oxford handbook of memory (pp. 33-43). New York: Oxford University Press.

Van der Kolk, B. A., \& Fisler, R. (1995). Dissociation and the fragmentary nature of traumatic memories: Overview and exploratory study. Journal of Traumatic Stress, 8, 505-525.

Wade, K. A., Garry, M., Read, J. D., \& Lindsay, S. (2002). A picture is worth a thousand lies: Using false photographs to create false childhood memories. Psychonomic Bulletin and Review, 9, 597-603. 